Levinas's Politics 



\title{
LEVINAS'S POLITICS
}

JUSTICE, MERCY, UNIVERSALITY

Annabel Herzog

\author{
$\overline{\text { PENN }}$ \\ UNIVERSITY OF PENNSYLVANIA PRESS \\ PH I L A DEL PHIA
}




\title{
Haney Foundation Series
}

A volume in the Haney Foundation Series, established in 1961 with the generous support of Dr. John Louis Haney

Copyright $\odot 2020$ University of Pennsylvania Press

All rights reserved.

Except for brief quotations used for purposes of review or scholarly citation, none of this book may be reproduced in any form by any means without written permission from the publisher.

\author{
Published by \\ University of Pennsylvania Press \\ Philadelphia, Pennsylvania 19104-4112 \\ www.upenn.edu/pennpress \\ Printed in the United States of America \\ on acid-free paper \\ 1357791086642 \\ Library of Congress Cataloging-in-Publication Data
}

Names: Herzog, Annabel, author.

Title: Levinas's politics : justice, mercy, universality / Annabel Herzog.

Other titles: Haney Foundation series.

Description: 1st edition. | Philadelphia : University of Pennsylvania Press, [2020] | Series: Haney

Foundation series | Includes bibliographical references and index.

Identifiers: LCCN 2019031232 | ISBN 9780812251975 (hardcover)

Subjects: LCSH: Lévinas, Emmanuel-Political and social views. | Lévinas, Emmanuel-Ethics.

| Talmud-Political aspects. | Political ethics-Philosophy. | Jewish ethics.

Classification: LCC B2430.L484 H47 2020 | DDC 320.092-dc23

LC record available at https://lccn.loc.gov/2019031232 
For my children 

Mon rapport au Talmud est donc un rapport européen, vous comprenez, c'est très important.

And so, my relationship to the Talmud remains very European; please understand, it is very important.

-E. Levinas

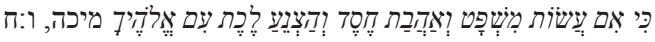

To act justly and to love mercy and to walk humbly with your God. (Micah 6:8) 
